\title{
ANALISIS INDEKS KEPUASAN MASYARAKAT (IKM) TERHADAP PELAYANAN TUTORIAL TATAP MUKA DI UPBJJ-UT BENGKULU
}

\author{
Dwi Kristanti \\ Universitas Terbuka \\ e-mail: dwik@ecampus.ut.ac.id
}

\begin{abstract}
Public services by the government in various sectors are sometimes perceived as not in line with public expectations. The purpose of this study was to analyze the quality of face-to-face tutorial services at Universitas Terbuka (UT) Regional Office in Bengkulu, using the Public Satisfaction Index (Indeks Kepuasan Masyarakat/IKM) method. This study used a quantitative descriptive approach. Data analysis techniques using the Public Satisfaction Index (IKM) approach, were calculated based on the weighted average value of each service element developed in the Regulation of Minister of State Aparatus and Bureaucratic Reform Number 16/2014. The findings of this study were that in general the assessment of public satisfaction index for Face to Face Tutorial held by UT Regional Office in Bengkulu obtained a Good Service criteria, with a Public Satisfaction Index value of 3.25 or converted to 81.16. It meant that the service performance was categorized as $B$ (Good). Through continuous improvement, it was expected that the value of the Public Satisfaction Index (IKM) for Face-to-Face Tutorial services at UT's Regional Office in Bengkulu can be maintained or improved in the following years.
\end{abstract}

Keywords: public satisfaction index, indeks kepuasan masyarakat, face to face tutorial, Universitas Terbuka Regional Office Bengkulu

Unit Program Belajar Jarak Jauh Universitas Terbuka (UPBJJ-UT) Bengkulu merupakan institusi yang menjalankan Sistem Pendidikan Tinggi Jarak Jauh (SPTJJ), yang senanatiasa memberikan layanan yang terbaik bagi mahasiswa, calon mahasiswa, alumni maupun masyarakat pada umumnya. Adapun pelayanan yang diberikan menyangkut layanan registrasi, layanan bahan ajar, layanan bantuan belajar, layanan penyelenggaraan ujian dan layanan tata usaha.

Sistem pembelajaran jarak jauh menuntut mahasiswa untuk dapat belajar mandiri, dengan mengakses beragam layanan belajar yang disediakan oleh Universitas Terbuka, seperti Tutorial Online, Tutorial Tatap Muka, Sistem Ujian Online, Webinar dan lain-lain.

Tingginya permintaan layanan Tutorial Tatap Muka, menuntut institusi untuk memberikan layanan yang memuaskan kepada mahasiswa sebagai pengguna. Adapun penentu kepuasan tersebut, dapat dilihat melalui indikator bahwa tidak adanya keluhan dari pengguna layanan (mahasiswa). Kaitannya dengan hal ini, maka organisasi pemberi layanan diharuskan untuk terus melakukan evaluasi kinerja dengan cara mengambil masukkan dari pengguna layanan. Di samping itu pula, UPBJJ-UT Bengkulu sebagai pemberi layanan perlu mengetahui sumber-sumber masukkan pelanggan dan mengetahui cara-cara di dalam mengatasi permasalahan yang dihadapi oleh pengguna layanan. 
Manajemen perguruan tinggi pada era keterbukaan merupakan langkah dalam mewujudkan kompetisi sehat melalui penyelenggaraan pendidikan yang berkualitas dan bermutu. Perguruan tinggi sebagai agen perubahan, dituntut untuk dapat menciptakan kader-kader pemimpin bangsa, yang pada dasarnya memerlukan suatu cara pengelolaan yang berbeda dengan pengelolaan institusi non pendidikan.

Masalah terpenting yang harus diperhatikan dalam manajemen pendidikan tinggi hari ini adalah bagaimana manajemen perguruan tinggi diatur dalam suatu administrasi yang rapi, efisien dan transparan. Sehingga pengelola perguruan tinggi dituntut untuk memikirkan bagaimana menerapkan sistem mutu, agar universitas sebagai lembaga yang melayani pendidikan tinggi kepada masyarakat mampu memberikan nilai lebih serta meningkatkan daya tarik bagi para calon mahasiswa untuk melanjutkan studinya.

Pemilihan metode pengukuran kualitas pelayanan berdasarkan IKM, dipilih karena menurut pengamatan yang dilakukan di lapangan terdapat beberapa indikator IKM yang belum terpenuhi oleh layanan yang dilakukan UPBJJ-UT. Ketertarikan menggunakan metode ini, karena operasionalisasi indikator yang dikembangkan IKM sangat praktis dan memberikan gambaran yang jelas.

Namun dalam perkembangannya, survey kepuasan masyarakat yang dikembangkan oleh Kementerian PAN dan RB mengalami pembaruan secara indikator penilaiannya. Hal ini sesuai dengan dikeluarkannya Peraturan Menteri Pendayagunaan Aparatur Negara dan Reformasi Birokrasi Nomor 16 Tahu 2014 tentang Pedoman Survei Kepuasaan Masyarakat Terhadap Penyelenggaraan Pelayanan Publik, yang menganulir aturan sebelumnya yang menjelaskan indikator penilaian sebanyak 14 unsur menjadi 9 unsur. Selanjutnya diharapkan hasil survey mampu diketahui secara luas kepada masyarakat dan dilakukan secara berkala minimal 1 (satu) kali dalam setahun.

Perlunya survey pengukuran kepuasan masyarakat terhadap pelayanan pendidikan tinggi, khususnya dalam studi ini adalah pelayanan Tutorial Tatap Muka bagi mahasiswa di UPBJJ-UT Bengkulu, sangat dibutuhkan untuk mengetahui tingkat keberhasilan dari masing-masing Kelompok Belajar (Pokjar). Pokjar merupakan ujung tombak pelayanan (street level bureaucracy), yang dimiliki masing-masing UPBJJ-UT dalam mendekatkan pelayanannya kepada mahasiswa yang tersebar luas di wilayah kerjanya. Selain itu, studi ini dimaksudkan juga sebagai bagian dari evaluasi yang harus diketahui oleh UPBJJ-UT Bengkulu, berkenaan dengan efektif dan efisiennya pelayanan Tutorial Tatap Muka (TTM) yang sudah berjalan sampai hari ini. Rekomendasi dari survey yang dilakukan diharapkan mampu memberikan gambaran, untuk kemudian dilakukan pembenahan pelayanan akademik yang berkualitas dan bermutu.

Berdasarkan latar belakang di atas, maka yang menjadi rumusan masalah dalam studi ini adalah Bagaimana kualitas pelayanan Tutorial Tatap Muka di UPBJJ-UT Bengkulu berdasarkan metode Indeks Kepuasan Masyarakat (IKM)? Adapun tujuan dari studi ini adalah untuk menganalisis kualitas pelayanan Tutorial Tatap Muka di UPBJJ-UT Bengkulu dengan metode Indeks Kepuasan Masyarakat (IKM).

\section{TINJAUAN PUSTAKA}

Pelayanan publik oleh aparatur pemerintah dewasa ini masih banyak dijumpai kelemahan sehingga belum dapat memenuhi kualitas yang diharapkan masyarakat. Hal ini ditandai dengan masih adanya berbagai keluhan masyarakat yang disampaikan melalui media massa, sehingga dapat menimbulkan citra yang kurang baik terhadap aparatur pemerintah. Mengingat fungsi utama pemerintah adalah melayani masyarakat maka pemerintah perlu terus berupaya meningkatkan kualitas pelayanan. 
Pelayanan dipahami sebagai kegiatan yang dilakukan oleh seseorang atau sekelompok orang dengan landasan faktor material melalui sistem, prosedur dan metode tertentu dalam rangka usaha memenuhi kepentingan orang lain sesuai haknya. Faktor material adalah faktor organisasi yang menimbulkan hak dan kewajiban baik keluar maupun ke dalam sebagaimana tercantum pada pasal-pasal dalam Undang-Undang Dasar 1945 (Moenir, 1998). Organisasi publik yang dalam pengembangan layanannya dikelola oleh birokrasi, dituntut untuk menunjukkan kinerja yang baik, yaitu dengan melakukan kegiatan pemenuhan urusan dan kepentingan publik, dengan lebih produktif, berkualitas, reponsif, responsibel dan akuntabel (Dwiyanto, 2006). Pelayaan Publik (Public Service) oleh birokrasi publik merupakan salah satu perwujudan dari fungsi aparatur negara sebagai abdi masyarakat disamping sebagai abdi negara. Pelayanan publik oleh birokrasi publik dimaksudkan untuk mensejahterakan masyarakat (warga negara) dari satu negara kesejahteraan (welfare state).

Terciptanya kualitas pelayanan tentunya akan menciptakan kepuasan terhadap pengguna pelayanan. Sebagai salah satu wujud dari implementasi kebijakan otonomi daerah maka indeks kepuasaan pelayanan publik merupakan salah satu strategi untuk mengatasi adanya maladministrasi dalam usaha meningkatkan kinerja aparatur publik, untuk itu maka diperlukan perhatian khusus dan mendalam terhadap pelayanan yang diberikan, apakah pemerintah daerah telah memberikan kepuasan pelanggan atau penerima layanan atau sebaliknya. Kepuasan pelanggan akan dapat mendukung tercapainya indikator keberhasilan pelaksanaan otonomi daerah begitu pula sebaliknya. Peranan pelayanan sangat penting artinnya di dalam penyelenggaraan pemerintahan terlebih pada pelakasanaan otonomi daerah karena dengan kebijakan otonomi daerah, maka daerah harus mampu mengelola daerahnya secara mandiri (Ganie-Rochman, 2000).

Selanjutnya, Viljoen (dalam Ratminto, 2005) menjelaskan aspek penting pelayanan, yang dapat dipakai sebagai acuan dalam menentukan SPM, meliputi:

a. Identifikasi kebutuhan konsumen

b. Pelayanan terpadu

c. Sistem yang mendukung

d. Semua karyawan bertanggungjawab atas pelayanan

e. Tangani keluhan

f. Terus berinovasi

g. Karyawan sama pentingnya dengan konsumen

Hadirnya Permen PAN dan RB Tahun 2014 ini, untuk menganulir Keputusan Menteri Pendayagunaan Aparatur Negara Nomor: Kep/25/M.PAN/2/2004 tentang Pedoman Umum Penyusunan Indeks Kepuasan Masyarakat Unit Pelayanan Organisasi Publik (Pemerintah). Dijelaskan bahwa Permen PAN dan RB Nomor 16 Tahun 2014 bertujuan untuk mengukur kepuasan masyarakat sebagai pengguna layanan dan meningkatkan kualitas penyelenggaraan pelayanan publik. Sarannya adalah untuk mendorong partisipasi masyarakat sebagai penguna layanan dalam menilai kinerja penyelenggara pelayanan, mendorong penyelenggara pelayanan untuk meningkatkan kualitas pelayanan, serta mendorong setiap instansi untuk lebih inovatif dalam menyelenggarakan pelayanan publik.

Kepmen PAN dan RB Nomor 16 Tahun 2014 menetapkan 9 (sembilan) unsur yang terkandung di dalam pelaksanaan pelayanan publik, yaitu:

1. Persyaratan dalam arti syarat yang harus dipenuhi dalam pengurusan suatu jenis pelayanan, baik yang bersifat teknis maupun administratif. 
2. Prosedur yang menggambarkan tata cara pelayanan yang dibakukan bagi pemberi dan penerima layanan, termasuk pengaduan.

3. Waktu pelayanan atau rentang waktu yang dibutuhkan menyelesaikan seluruh proses pelayanan setiap jenis pelayanan.

4. Biaya/tarif/ongkos yang dibebankan kepada penerima layanan ketika memperoleh layanan dari penyelenggara yang besarnya sesuai kesepakatan antara kedua pihak.

5. Produk spesifikasi jenis layanan sebagai hasil dari setiap spesifikasi jenis layanan yang diberikan.

6. Kompetensi pelakana dalam arti kemampuan yang harus dimiliki oleh pelaksana meliputi pengetahuan, keahlian, keterampilan dan pengalaman.

7. Perilaku pelaksana yaitu sikap petugas dalam memberikan pelayanan.

8. Maklumat pelayanan sebagai pernyataan kesanggupan dan kewajiban pelaksana/petugas untuk melaksanakan pelayanan sesuai standar pelayanan.

9. Penanganan pengaduan, saran dan masukan yang menggambarkan tata cara pelaksanaan penanganan pengaduan dan tindak lanjutnya.

\section{METODE}

Studi ini menggunakan pendekatan deskriptif kuantitatif, dengan metode survey kepuasan masyarakat terhadap pelayanan Tutorial Tatap Muka (TTM) di Unit Program Belajar Jarak Jauh Universitas Terbuka (UPBJJ-UT) Bengkulu. Dimana instrumen studi dikembangkan melalui sembilan unsur yang dijelaskan di dalam Peraturan Menteri Pendayagunaan Aparatur Negara dan Reformasi Birokrasi Nomor 16 Tahun 2014 Tentang Pedoman Survei Kepuasan Masyarakat Terhadap Penyelenggaraan Pelayanan Publik.

Pengumpulan data dilakukan dengan menyebarkan instrumen berupa kuesioner. Kuesioner disusun berdasarkan Peraturan Menteri Pendayagunaan Aparatur Negara dan Reformasi Birokrasi Nomor 16 Tahun 2014 Tentang Pedoman Survei Kepuasan Masyarakat Terhadap Penyelenggaraan Pelayanan Publik.

Menurut Kepmenpan diatas, unsur indeks kepuasan masyarakat yang ditetapkan dalam studi ini, dengan menetapkan 9 (sembilan) unsur minimal yang harus ada untuk dasar pengukuran, yaitu:

1. Persyaratan pelayanan;

2. Prosedur dan tata cara;

3. Ketepatan waktu pelayanan;

4. Kesesuaian biaya pelayanan;

5. Kejelasan dan kepastian;

6. Kompetensi (kemampuan) pelaksana;

7. Perilaku (kesopanan dan keramahan) pelaksana;

8. Maklumat pelayanan; dan

9. Penanganan pengaduan, saran dan masukan

Kesembilan indikator di atas digunakan sebagai bahan penyusunan butir-butir pertanyaan dalam kuesioner survey kepuasaan pengguna layanan. Penyusunan butir-butir pertanyaan tersebut diperinci seperti pada Tabel 1. 
Tabel 1. Daftar Kuesioner IKM

\begin{tabular}{|c|c|}
\hline Indikator & Daftar Pertanyaan \\
\hline Persyaratan pelayanan & $\begin{array}{l}\text { Bagaimana pendapat Anda mengenai kesesuaian persyaratan } \\
\text { yang diminta oleh UPBJJ-UT Bengkulu untuk mengikuti Tutorial } \\
\text { Tatap Muka (TTM)? }\end{array}$ \\
\hline Prosedur dan tata cara & $\begin{array}{l}\text { Bagaimana pemahaman Anda mengenai prosedur pelayanan } \\
\text { Tutorial Tatap Muka di UPBJJ-UT Bengkulu? }\end{array}$ \\
\hline Ketepatan waktu pelayanan & $\begin{array}{l}\text { Bagaimana pendapat Anda tentang ketepatan pelaksanaan } \\
\text { Tutorial Tatap Muka terhadap jadwal pelaksanaannya? }\end{array}$ \\
\hline Kesesuaian biaya pelayanan & $\begin{array}{l}\text { Bagaimana pendapat Anda tentang kesesuaian antara biaya } \\
\text { Tutorial Tatap Muka yang dibayarkan dengan biaya yang telah } \\
\text { ditetapkan? }\end{array}$ \\
\hline Kejelasan dan kepastian & $\begin{array}{l}\text { Bagaimana pendapat Anda tentang kejelasan dan kepastian } \\
\text { petugas Pokjar yang melayani Tutorial Tatap Muka? }\end{array}$ \\
\hline $\begin{array}{l}\text { Kompetensi (kemampuan) } \\
\text { pelaksana }\end{array}$ & $\begin{array}{l}\text { Bagaimana pendapat Anda tentang kemampuan Tutor dalam } \\
\text { memberikan layanan belajar Tutorial Tatap Muka? }\end{array}$ \\
\hline $\begin{array}{l}\text { Perilaku (kesopanan dan } \\
\text { keramahan) pelaksana }\end{array}$ & $\begin{array}{l}\text { Bagaimana pendapat Anda tentang kesopanan dan keramahan } \\
\text { petugas Pokjar dan Tutor dalam memberikan pelayanan Tutorial } \\
\text { Tatap Muka? }\end{array}$ \\
\hline Maklumat pelayanan & $\begin{array}{l}\text { Bagaimana pendapat Anda tentang kejelasan pernyataan } \\
\text { kesanggupan dan kewajiban UPBJJ-UT Bengkulu dalam } \\
\text { melaksanakan layanan Tutorial Tatap Muka sesuai dengan } \\
\text { standar pelayanan? }\end{array}$ \\
\hline $\begin{array}{l}\text { Penanganan pengaduan, } \\
\text { saran dan masukan }\end{array}$ & $\begin{array}{l}\text { Bagaimana pendapat Anda tentang penanganan pengaduan, } \\
\text { saran dan masukan yang berkaitan dengan proses pelaksanaan } \\
\text { Tutorial Tatap Muka? }\end{array}$ \\
\hline
\end{tabular}

Studi ini mengembangkan unsur yang ditetapkan di dalam Peraturan Menteri Pendayagunaan Aparatur Negara dan Reformasi Birokrasi Nomor 16 Tahun 2014, dimana aturan tersebut mengatur tentang Pedoman Survei Kepuasaan Masyarakat Terhadap Penyelenggaraan Pelayanan Publik, yaitu menggunakan nilai rata-rata tertimbang dari masing-masing unsur pelayanan. Untuk perhitungan indeks kepuasan masyarakat terdapat 9 (sembilan) unsur pelayanan yang dikaji, setiap unsur pelayanan memiliki penimbang yang sama, dengan rumus sebagai berikut:

$$
\text { Bobot nilai rata-rata tertimbang }=\frac{\text { Jumlahbobot }}{\text { Jumlahunsur }}=\frac{1}{9}=0,11
$$

Untuk memperoleh nilai IKM pada unit pelayanan, digunakan pendekatan nilai rata-rata tertimbang dengan rumus sebagai berikut: 


$$
\text { IKM }=\frac{\text { Total dari Nilai Persepsi Per }- \text { Unsur }}{\text { Jumlahunsur }} \times \text { Nilai penimbang }
$$

Untuk memudahkan interprestasi terhadap penilaian IKM yaitu antara 25-100, maka hasil penilaian tersebut, dikonversikan dengan nilai dasar 25 , dengan rumus sebagai berikut:

\section{IKM Unit Pelayanan x 25}

Sehingga diperoleh hasil penilaian Indeks Kepuasan Masyarakat (IKM) dalam studi ini menghasilkan nilai persepsi, interval IKM, interval konversi IKM, mutu pelayanan dan kinerja unit pelayanan.

Tabel 2. Nilai Persepsi, Interval IKM, Interval Konversi IKM, Mutu Pelayanan dan Kinerja Unit Pelayanan

\begin{tabular}{ccccc}
\hline $\begin{array}{c}\text { Nilai } \\
\text { Persepsi }\end{array}$ & Nilai Interval IKM & $\begin{array}{c}\text { Nilai Interval Konversi } \\
\text { IKM }\end{array}$ & $\begin{array}{c}\text { Mutu } \\
\text { Pelayanan }\end{array}$ & $\begin{array}{c}\text { Kinerja Unit } \\
\text { Pelayanan }\end{array}$ \\
\hline 1 & $1,00-1,75$ & $25-43,75$ & $\mathrm{D}$ & Tidak baik \\
2 & $1,76-2,50$ & $43,76-62,50$ & $\mathrm{C}$ & Kurang baik \\
3 & $2,51-3,25$ & $62,51-81,25$ & B & Baik \\
4 & $3,26-4,00$ & $81,26-100$ & A & Sangat baik \\
\hline
\end{tabular}

Data yang terkumpul diolah dengan menggunakan aplikasi Microsoft Excel atau Statistical Package for Social Sciences (SPSS), sehingga di dapatkan hasil yang lebih komprehensif mengenai survey kepuasan masyarakat terhadap pelayanan Tutorial Tatap Muka yang diselenggarakan oleh UPBJJ-UT Bengkulu.

Setelah diperolehnya hasil pengolahan data kepuasan masyarakat, maka perlu dilakukannya analisa terhadap masing-masing unsur yang di survey, baik yang bersifat teknis maupun non teknis secara keseluruhan.

Analisis dilakukan untuk menggambarkan data variabel yang terkumpul, tanpa bermaksud untuk memberikan kesimpulan. Hasil analisis ini merupakan deskripsi hasil temuan survey yang telah diolah sebelumnya menjadi seperti frekuensi dan prosentase yang diwujudkan ke dalam gambar atau perhitungan deskriptif dari masing-masing unsur yang di survey.

Untuk mempermudah pemahaman metode diatas, berikut ini penulis mencoba memberikan contoh, apabila diketahui nilai rata-rata unsur dari masing-masing unit pelayanan adalah sebagaimana Tabel 3.

Tabel 3. Contoh Penilaian Unsur Pelayanan

\begin{tabular}{lc}
\hline \multicolumn{1}{c}{ Unsur Pelayanan } & $\begin{array}{c}\text { Nilai Unsur } \\
\text { Pelayanan }\end{array}$ \\
\hline Persyaratan pelayanan & 3,45 \\
Prosedur dan tata cara & 2,65 \\
Ketepatan waktu pelayanan & 3,54 \\
Kesesuaian biaya pelayanan & 2,54 \\
\hline
\end{tabular}


Tabel 3. Lanjutan

\begin{tabular}{lc}
\hline \multicolumn{1}{c}{ Unsur Pelayanan } & $\begin{array}{c}\text { Nilai Unsur } \\
\text { Pelayanan }\end{array}$ \\
\hline Kejelasan dan kepastian & 2,13 \\
Kompetensi (kemampuan) pelaksana & 3,56 \\
Perilaku (kesopanan dan keramahan) pelaksana & 3,72 \\
Maklumat pelayanan & 3,45 \\
Penanganan pengaduan, saran dan masukan & 3,82 \\
\hline
\end{tabular}

Maka untuk mengetahui nilai indeks unit pelayanan dihitung dengan cara, sebagai berikut:

$(3,45 \times 0,11)+(2,65 \times 0,11)+(3,54 \times 0,11)+(2,54 \times 0,11)+(2,13 \times 0,11)+(3,56 \times 0,11)$

$+(3,72 \times 0,11)+(3,45 \times 0,11)+(3,82 \times 0,11)=$ Nilai indeks adalah 3,175

Berdasarkan hasil dari nilai indeks di atas, maka dapat disimpulkan sebagai berikut:

a. Nilai IKM setelah dikonversi (Nilai Indeks x Nilai Dasar) adalah 3,175 x $25=79,37$.

b. Berdasarkan hasil nilai konversi diatas sebesar 79,37 , maka mutu pelayanan yang didapat adalah bernilai $\mathbf{B}$.

c. Sehingga berdasarkan mutu pelayanan diatas, maka kinerja unit pelayanan dapat di kategorikan Baik.

Berangkat dari contoh di atas, maka prioritas peningkatan kualitas pelayanan, dapat dilihat melalui prioritas peningkatan organisasi yang memiliki nilai paling rendah, sedangkan unsur yang memiliki nilai cukup tinggi harus tetap dipertahankan.

\section{PEMBAHASAN}

Pengukuran kepuasan masyarakat dalam survey ini menggunakan skala indeks. Indeks Kepuasan Masyarakat merupakan suatu nilai atau tingkatan untuk mengukur nilai kepuasan masyarakat terhadap pelayanan Tutorial Tatap Muka atau TTM yang diselenggarakan oleh UPBJJUT Bengkulu. Untuk menilai indeks kepuasan masyarakat, dalam survey ini menggunakan skala likert. Adapun maksud penskoran menggunakan skala likert adalah dengan skor 1 sampai 4 . Analisis selanjutnya mengkonversi ke dalam skala 100, dan kategorisasi mutu pelayanan Tutorial Tatap Muka (TTM) yang diselenggarakan oleh UPBJJ-UT Bengkulu.

Berdasarkan hasil Indeks Kepuasan Masyarakat, studi ini menghasilkan penilaian IKM secara keseluruhan seperti pada Tabel 4.

Tabel 4. Hasil Indeks Kepuasan Masyarakat terhadap Pelayanan Tutorial Tatap Muka di UPBJJ-UT Bengkulu

\begin{tabular}{lcccc}
\hline \multicolumn{1}{c}{ Unsur Pelayanan } & Nilai IKM & $\begin{array}{c}\text { Nilai Konversi } \\
\text { IKM }\end{array}$ & $\begin{array}{c}\text { Mutu } \\
\text { Pelayanan }\end{array}$ & Kinerja \\
\hline Persyaratan pelayanan & 3,25 & 81,17 & B & Baik \\
Prosedur dan tata cara & 3,18 & 79,56 & B & Baik \\
Ketepatan waktu pelayanan & 3,25 & 81,15 & B & Baik \\
Kesesuaian biaya pelayanan & 3,27 & 81,67 & A & Sangat Baik \\
Kejelasan dan kepastian & 3,26 & 81,62 & A & Sangat Baik \\
\hline
\end{tabular}




\begin{tabular}{lcccc}
\hline Tabel 4. Lanjutan & \multicolumn{3}{c}{ Kinerja } \\
\hline \multicolumn{1}{c}{ Unsur Pelayanan } & Nilai IKM & $\begin{array}{c}\text { Nilai Konversi } \\
\text { IKM }\end{array}$ & $\begin{array}{c}\text { Mutu } \\
\text { Pelayanan }\end{array}$ & Sangat Baik \\
\hline Kemampuan & 3,28 & 82,00 & $\mathrm{~A}$ & Sangat Baik \\
Kesopanan dan keramahan & 3,42 & 85,44 & $\mathrm{~A}$ & Sangat Baik \\
Maklumat pelayanan & 3,37 & 84,27 & $\mathrm{~A}$ & Baik \\
$\begin{array}{l}\text { Penanganan pengaduan, saran dan } \\
\text { masukan }\end{array}$ & 3,24 & 80,88 & $\mathrm{~B}$ & Baik \\
\hline IKM Pelayanan TTM & $\mathbf{3 , 2 5}$ & $\mathbf{8 1 , 1 5}$ & $\mathbf{B}$ & \\
\hline
\end{tabular}

Berangkat dari data di atas, maka dapat dijelaskan bahwa indeks kepuasan pengguna layanan (mahasiswa), terhadap pelayanan Tutorial Tatap Muka (TTM) yang diselenggarakan oleh UPBJJ-UT Bengkulu, adalah memperoleh nilai 81,15. Nilai tertinggi dari hasil studi ini adalah unsur pelayanan "kesopanan dan keramahan", dengan mendapat nilai rata-rata 3,42 dan nilai rata-rata terendah ada pada unsur pelayanan "prosedur dan tata cara", dengan mendapatkan nilai 79,56 atau dengan nilai rata-rata sebesar 3,18.

Kondisi di atas menunjukkan bahwa mutu indeks kepuasan masyarakat terhadap pelayanan Tutorial Tatap Muka (TTM) yang diselenggarakan oleh UPBJJ-UT Bengkulu, telah mencapai kategori atau klasifikasi Baik atau dengan nilai mutu pelayanan adalah $\mathbf{B}(81,15)$.

Hal di atas membuktikan bahwa untuk melakukan perbaikan kinerja pelayanan Tutorial Tatap Muka (TTM) oleh UPBJJ-UT Bengkulu selanjutnya akan lebih ringan, mengingat beberapa unsur pelayanan sudah mendapatkan predikat sangat baik, seperti aspek unsur pelayanan terhadap kesesuaian biaya pelayanan, kemampuan, kejelasan dan kepastian, kesopanan dan keramahan, serta maklumat pelayanan.

Melihat hasil IKM ini dapat dikatakan bahwa pelaksanaan layanan Tutorial Tatap Muka (TTM) yang diselenggarakan oleh UPBJJ-UT Bengkulu sudah berjalan dengan baik, dan diharapkan mampu mempertahankan atau bahkan mampu meningkatkan indeks kepuasan masyarakat menjadi sangat baik, atau dapat dikatakan mampu memiliki kinerja pelayanan yang sangat baik.

\section{Persyaratan Pelayanan}

Unsur pelayanan tentang persyaratan dimulai dengan pertanyaan, "Bagaimana pendapat Anda mengenai kesesuaian persyaratan yang diminta oleh UPBJJ-UT Bengkulu untuk mengikuti Tutorial Tatap Muka (TTM)?".

Berdasarkan pernyataan responden mengenai pernyataan "Persyaratan Pelayanan", sudah berjalan dengan baik, hal ini dapat dilihat sebanyak 375 responden menyatakan sangat sesuai dan hanya 6 responden yang menyatakan tidak sesuai. Sebanyak 375 orang dari total 1.386 responden memberikan pernyataan persyaratan pelayanan sangat sesuai. Selanjutnya sebanyak 984 orang memberikan pernyataan sesuai, sedangkan 21 orang lainnya menyatakan kurang sesuai dan 6 orang selebihnya menyatakan tidak sesuai.

Dengan demikian total keseluruhan nilai rata-rata pada unsur persyaratan pelayanan adalah 3,25 atau sebanding dengan nilai 81,17 , yang artinya nilai kinerja pada unsur ini B (Baik). 


\section{Prosedur dan Tata Cara Pelayanan}

Unsur pelayanan tentang prosedur dan tata cara pelayanan dimulai dengan pertanyaan, "Bagaimana pendapat Anda mengenai kesesuaian persyaratan yang diminta oleh UPBJJ-UT Bengkulu untuk mengikuti Tutorial Tatap Muka (TTM)?"

Adapun responden merespon pernyataan "Prosedur dan Tata Cara Pelayanan", sudah berjalan dengan baik, hal ini dapat dilihat sebanyak 266 responden menyatakan sangat mudah dan hanya 3 responden yang menyatakan tidak mudah. Untuk lebih jelasnya berikut penilaian IKM dari unsur Prosedur dan Tata Cara Pelayanan.

Sebanyak 266 orang dari 1.386 responden, yang telah memberikan pernyataan persyaratan pelayanan sangat sesuai. Selanjutnya sebanyak 1.110 orang memberikan pernyataan sesuai, sedangkan 7 orang lainnya menyatakan kurang sesuai dan 3 orang selebihnya menyatakan tidak sesuai.

Dengan demikian total keseluruhan nilai rata-rata pada unsur persyaratan pelayanan adalah 3,18 atau sebanding dengan nilai 79,56, yang artinya nilai kinerja pada unsur ini B (Baik).

\section{Ketepatan Waktu}

Unsur pelayanan tentang ketepatan waktu dimulai dengan pertanyaan, "Bagaimana pemahaman Anda mengenai prosedur pelayanan Tutorial Tatap Muka di UPBJJ-UT Bengkulu?". responden merespon pernyataan "Ketepatan Waktu", sudah berjalan dengan baik, hal ini dapat dilihat sebanyak 360 responden menyatakan selalu tepat dan hanya 1 responden yang menyatakan selalu tidak tepat. Untuk lebih jelasnya berikut tabel penilaian IKM dari unsur Prosedur dan Tata Cara Pelayanan.

Sebanyak 360 orang dari total 1.386 responden memberikan pernyataan bahwa pelayanan TTM selalu tepat waktu. Selanjutnya sebanyak 1.008 orang memberikan pernyataan waktu pelayanan bayaknya tepatnya, sedangkan 7 orang lainnya menyatakan pelayanan TTM kadangkadang tepat waktu dan 1 orang selebihnya menyatakan pelayanan TTM selalu tidak tepat waktu. Dengan demikian total keseluruhan nilai rata-rata pada unsur ketepatan waktu adalah 3,25 atau sebanding dengan nilai 81,15, yang artinya nilai kinerja pada unsur ini B (Baik).

\section{Kesesuaian Biaya Pelayanan}

Unsur pelayanan tentang kesesuaian biaya pelayanan dimulai dengan pertanyaan, "Bagaimana pendapat Anda tentang ketepatan pelaksanaan Tutorial Tatap Muka terhadap jadwal pelaksanaannya?". Selanjutnya, responden merespon pernyataan "Kesesuaian Biaya", sudah berjalan cukup baik, hal ini dapat dilihat sebanyak 384 responden menyatakan selalu sesuai dan hanya 2 responden yang menyatakan selalu tidak sesuai. Untuk lebih jelasnya berikut tabel penilaian IKM dari unsur Kesesuaian Biaya.

Sebanyak 384 orang dari total 1.386 responden memberikan pernyataan bahwa pelayanan TTM selalu sesuai biaya yang ditetapkan. Selanjutnya sebanyak 990 orang memberikan pernyataan biaya pelayanan banyak sesuainya, sedangkan 10 orang lainnya menyatakan pelayanan TTM kadang-kadang sesuai dalam menetapkan biayanya dan 2 orang selebihnya menyatakan pelayanan TTM selalu tidak sesuai dalam hal penetapan biaya. Dengan demikian total keseluruhan nilai ratarata pada unsur kesesuaian biaya adalah 3,27 atau sebanding dengan nilai 81,67 , yang artinya nilai kinerja pada unsur ini A (Sangat Baik). 


\section{Kejelasan dan Kepastian}

Unsur pelayanan tentang kejelasan dan kepastian dimulai dengan pertanyaan, "Bagaimana pendapat Anda tentang kejelasan dan kepastian petugas Pokjar yang melayani Tutorial Tatap Muka?"

Indikator responden merespon pernyataan "Kejelasan dan Kepastian", sudah berjalan cukup baik, hal ini dapat dilihat sebanyak 388 responden menyatakan sangat jelas dan hanya 2 responden yang menyatakan tidak jelas. Untuk lebih jelasnya berikut tabel penilaian IKM dari unsur Kejelasan dan Kepastian.

Responden memberikan pernyataan tentang "Kejelasan dan Kepastian", sudah berjalan cukup baik, hal ini dapat dilihat sebanyak 388 responden menyatakan sangat jelas dan hanya 2 responden yang menyatakan tidak jelas. Untuk lebih jelasnya berikut tabel penilaian IKM dari unsur Kejelasan dan Kepastian.

Diketahui bahwa sebanyak 388 orang dari total 1.386 responden memberikan pernyataan bahwa pelayanan TTM pelaksanaannya sangat jelas. Selanjutnya sebanyak 985 orang memberikan pernyataan bahwa pelayanan yang diberikan jelas dan pasti, sedangkan 11 orang lainnya menyatakan pelayanan TTM kadang-kadang kurang jelas dalam pelaksanaannya dan 2 orang selebihnya menyatakan pelayanan TTM selalu tidak jelas dalam hal memberikan pelayanan.

Dengan demikian total keseluruhan nilai rata-rata pada unsur kejelasan dan kepastian adalah 3,26 atau sebanding dengan nilai 81,62, yang artinya nilai kinerja pada unsur ini $A$ (Sangat Baik).

\section{Kompetensi (Kemampuan) Pelaksana}

Unsur pelayanan tentang kompetensi atau kemampuan pelaksana dimulai dengan pertanyaan, "Bagaimana pendapat Anda tentang kemampuan Tutor dalam memberikan layanan belajar Tutorial Tatap Muka?”. Untuk itu hasil tanggapan responden dapat dijelaskan sebagai berikut.

Dapat diketahui bahwa sebanyak 397 orang dari total 1.386 responden memberikan pernyataan bahwa tutor dalam memberikan layanan belajar TTM sudah sangat mampu. Selanjutnya sebanyak 980 orang memberikan pernyataan bahwa tutor dalam memberikan layanan belajar TTM sudah dapat dikatakan mampu atau cukup kompeten, sedangkan 7 orang lainnya menyatakan pelayanan TTM yang diberikan oleh tutor, dapat dikatakan masih kurang mampu dan 2 orang selebihnya menyatakan ada sebagian tutor yang tidak mampu dalam memberikan layanan belajar.

Dengan demikian total keseluruhan nilai rata-rata pada unsur kemamuan atau kompetensi adalah 3,28 atau sebanding dengan nilai 82,00, yang artinya nilai kinerja pada unsur ini $A$ (Sangat Baik).

\section{Perilaku (Kesopanan dan Keramahan)}

Unsur pelayanan tentang perilaku pelaksana dimulai dengan pertanyaan, "Bagaimana pendapat Anda tentang kesopanan dan keramahan petugas Pokjar dan Tutor dalam memberikan pelayanan Tutorial Tatap Muka?

Berdasarkan pernyataan responden tentang "Perilaku Pelaksana", sudah berjalan dengan baik, hal ini dapat dilihat sebanyak 589 responden menyatakan tutor dan petugas Pokjar sudah melayani mahasiswa dengan sangat sopan ramah, sedangkan 2 responden lainnya menyatakan masih adanya tutor maupun petugas Pokjar yang tidak sopan dan ramah. Untuk lebih jelasnya berikut tabel penilaian IKM dari unsur Perilaku Pelaksana. 
Diketahui bahwa sebanyak 589 orang dari total 1.386 responden memberikan pernyataan bahwa tutor dan petugas Pokjar dalam memberikan layanan belajar TTM sudah sangat sopan dan ramah terhadap mahasiswa. Selanjutnya sebanyak 789 orang memberikan pernyataan bahwa tutor dan petugas Pokjar dalam memberikan layanan belajar TTM sudah dapat dikatakan sopan dan ramah, sedangkan 6 orang lainnya menyatakan tutor maupun petugas Pokjar dalam melayani mahasiswa masih kurang sopan dan ramah. Adapun 2 orang lainnya menyatakan sebagian tutor dan pengurus pokjar tidak sopan dan ramah dalam memberikan layanan kepada mahasiswa.

Dengan demikian total keseluruhan nilai rata-rata pada unsur perilaku pelaksana adalah 3,42 atau sebanding dengan nilai 85,44 , yang artinya nilai kinerja pada unsur ini A (Sangat Baik).

\section{Maklumat Pelayanan}

Unsur pelayanan tentang maklumat pelayanan dimulai dengan pertanyaan, "Bagaimana pendapat Anda tentang kejelasan pernyataan kesanggupan dan kewajiban UPBJJ-UT Bengkulu dalam melaksanakan layanan Tutorial Tatap Muka sesuai dengan standar pelayanan?"

Diketahui bahwa pernyataan responden tentang "Maklumat Pelayanan", sudah berjalan dengan baik, hal ini dapat dilihat sebanyak 524 responden menyatakan bahwa ada kejelasan pernyataan kesanggupan bagi UPBJJ-UT Bengkulu dalam memberikan layanan TTM yang sesuai dengan standar pelayanan, sedangkan pernyataan tidak jelas hanya ada 1 responden. Untuk lebih jelasnya berikut tabel penilaian IKM dari unsur Maklumat Pelayanan.

Sebanyak 524 orang dari total 1.386 responden memberikan pernyataan bahwa maklumat pelayanan yang disampaikan oleh pihak UPBJJ-UT Bengkulu sudah sangat jelas. Selanjutnya sebanyak 853 orang memberikan pernyataan bahwa UPBJJ-UT Bengkulu cukup jelas dalam memberikan pernyataan kesanggupan menyelenggarakan TTM sesuai standar pelayanan, sedangkan 6 orang lainnya menyatakan UPBJJ-UT Bengkulu kurang jelas dalam menyanggupi penyelenggaraan TTM yang sesuai dengan standar pelayanan. Adapun 1 orang lainnya menyatakan adanya ketidakjelasan UPBJJ-UT Bengkulu dalam melaksanakan TTM yang sesuai dengan standar pelayanan.

Dengan demikian total keseluruhan nilai rata-rata pada unsur perilaku pelaksana adalah 3,37 atau sebanding dengan nilai 84,27, yang artinya nilai kinerja pada unsur ini A (Sangat Baik).

\section{Penanganan Pengaduan, Saran dan Masukan}

Unsur pelayanan tentang penanganan pengaduan, saran dan masukan dimulai dengan pertanyaan, "Bagaimana pendapat Anda tentang kejelasan pernyataan kesanggupan dan kewajiban UPBJJ-UT Bengkulu dalam melaksanakan layanan Tutorial Tatap Muka sesuai dengan standar pelayanan?"

Diketahui bahwa responden memberikan pernyataan tentang "Penanganan Pengaduan, Saran dan Masukan", sudah berjalan dengan baik, hal ini dapat dilihat sebanyak 366 responden menyatakan bahwa penanganan pengaduan, saran dan masalah sudah berjalan sangat baik, sedangkan pernyataan tidak baik terdapat 9 responden. Untuk lebih jelasnya berikut tabel penilaian IKM dari unsur Penanganan Pengaduan, Saran dan Masukan.

Sebanyak 366 orang dari total 1.386 responden memberikan pernyataan bahwa proses penanganan pengaduan, saran dan masalah oleh UPBJJ-UT Bengkulu sangat baik. Selanjutnya sebanyak 989 orang memberikan pernyataan bahwa UPBJJ-UT Bengkulu dalam penanganan pengaduan, saran dan masalah belum ditetapkan sesuai standar pelayanan, sedangkan 22 orang lainnya menyatakan UPBJJ-UT Bengkulu kurang baik dalam memanfaatkan kanal penanganan 
pengaduan, saran dan masalah. Adapun 9 orang lainnya menyatakan bahwa penanganan pengaduan, saran dan masalah oleh UPBJJ-UT dalam prosesnya tidak dijalankan engan tidak baik.

Dengan demikian total keseluruhan nilai rata-rata pada unsur perilaku pelaksana adalah 3,36 atau sebanding dengan nilai 80,88, yang artinya nilai kinerja pada unsur ini B (Baik).

\section{PENUTUP}

Secara umum penilaian indeks kepuasan masyarakat terhadap layanan Tutorial Tatap Muka (TTM) yang diselenggarakan oleh UPBJJ-UT Bengkulu, mendapatkan kriteria pelayanan yang baik, dengan nilai IKM 3,25 atau dikonversi dengan nilai 81,16 yang artinya mendapat kinerja pelayanan yang berkategori $B$ (Baik).

Selanjutnya, berdasarkan sejumlah aspek yang dinilai responden, dengan pengembangan indikator yang dipertegas melalui regulasi Peraturan Menteri Nomor 16 Tahun 2014, bahwa terdapat catatan bagi UPBJJ-UT Bengkulu untuk dapat melakukan perbaikan di tahun mendatang, terkait dengan rendahnya penilaian responden terhadap indikator Prosedur dan Tata Cara, yang mendapatkan penilaian dibawah angka 80 .

Perbaikan terhadap indikator Prosedur dan Tata Cara, sangat penting untuk dilakukan oleh UPBJJ-UT Bengkulu, agar dapat meningkatkan layanan Tutoria Tatap Muka bagi penggunannya yaitu mahasiswa yang tergabung di dalam kelompok belajar (Pokjar). Indikator Prosedur dan Tata Cara, pada dasarnya belum mampu memenuhi ekspektasi pengguna layanan Tutorial Tatap Muka, mengingat layanan ini adalah bagian dari salah satu media belajar yang tertinggi secara nasional. Sehingga melalui perbaikan berkelanjutan yang akan dihasilkan, diharapkan nilai IKM pada tahuntahun berikutnya dapat dipertahankan atau setidaknya dapat ditingkatkan lagi.

\section{REFERENSI}

Dwiyanto, A. (2006). Reformasi Birokrasi Publik di Indonesia. Yogyakarta: Gadja Mada University Press.

Ganie-Rochman, M. (2000). Good Governance-Prinsip, Komponen, dan Penerapannya, dalam HAM: Penyelenggaraan Negara yang Baik dan Masyarakat Warga. Jakarta: Kompas HAM. Moenir, H.A.S. (1998). Manajemen Pelayanan Umum di Indonesia. Jakarta: Bumi Aksara. Peraturan Menteri Pendayagunaan Aparatur Negara dan Reformasi Birokrasi Nomor 16 Tahun 2014. Ratminto, A. S. (2005). Manajemen Pelayanan. Yogyakarta: Pustaka Pelajar. 